\title{
Malnutrition and clinical outcomes in surgical patients with colorectal disease
}

\author{
Victor Keniti Gomes NISHIYAMA ${ }^{1}$, Silvia Maria ALBERTINI ${ }^{2}$, Carla Maria Zordan Geraldo de MORAES ${ }^{1}$ \\ and Moacir Fernandes de GODOY ${ }^{3}$ and João Gomes NETINHO ${ }^{4}$
}

Received 26/7/2018 Accepted 10/9/2018

\begin{abstract}
Background - Malnutrition is a frequent condition among hospitalized patients and a factor of increased risk of postoperative complication. Objective - This study aimed to evaluate the impact of malnutrition on phase angle (PA), body water distribution and clinical outcomes in surgical patients with colorectal disease. Methods - This retrospective study was performed in a tertiary hospital with 40 patients admitted electively. In the preoperative evaluation, global subjective assessment and bioelectrical impedance analysis were performed to determine nutritional status, PA, extracellular water (ECW), intracellular water (ICW) and total body water (TBW). In postoperative evaluation, the length of hospital stay and severe complications, according to Clavien-Dindo classification, were determined. The optimal PA cutoff for malnutrition screening was determined by ROC curve analysis. Results - Seventeen (42.5\%) patients were diagnosed as malnourished and 23 (57.5\%) as well-nourished according to global subjective assessment. Twelve (30.0\%) patients developed severe complications. The malnourished group presented lower values of serum albumin $(P=0.012)$, hematocrit $(P=0.026)$ and PA $(P=0.002)$; meanwhile, ECW/ICW $(P=0.019)$ and ECW/TBW $(P=0.047)$ were higher. Furthermore, $58.8 \%$ of malnourished patients developed severe postoperative complications compared to $8.7 \%$ of well-nourished. Malnutrition was independent predictor of severe postoperative complications $(\mathrm{OR}=15.00$, IC: $2.63-85.68, P=0.002)$. The optimal PA cutoff obtained was $6.0^{\circ}(\mathrm{AUC}=0.82, P=0.001)$, yielding sensitivity, specificity, positive predictive value and negative predictive value of $76.5 \%, 87.0 \%, 81.3 \%$ and $83.4 \%$, respectively. Conclusion Malnutrition was an independent predictive factor for severe complications in patients underwent to elective major coloproctological surgery. Besides that, malnutrition was associated with lower PA values and greater ratio of ECW. The PA provided great accuracy in nutritional screening, implying a useful marker of malnutrition.
\end{abstract}

HEADINGS - Malnutrition. Electric impedance. Nutrition Assessment. Colorectal Surgery.

\section{INTRODUCTION}

Malnutrition is one of the main comorbidities of surgical patient. According to a systematic review published in 2017 by Correia et al. ${ }^{(1)}$, the prevalence of hospital malnutrition in Latin America ranged from $2.6 \%$ to $73.2 \%$. High rates of malnutrition were observed in patients who underwent gastrointestinal surgery on admission. Surgical trauma itself triggers a sequence of inflammatory events related to the metabolic response to trauma ${ }^{(2)}$. Consequently, pre-existing malnutrition associated with trauma sets negative factors in postoperative evolution, predisposing patients to greater morbidity and mortality rates ${ }^{(3)}$. Several studies have shown worse clinical outcomes in malnourished patients who underwent surgical procedure ${ }^{(4-6)}$.

Despite the variety of instruments for assessing nutritional status, there is no gold standard method. However, American Society for Parenteral and Enteral Nutrition (ASPEN) and Brazilian Nutrition Association (ABRAN) recommend using Global Subjective Assessment (SGA) as a nutritional screening tool, due to its good reproducibility, easy execution and high correlation with anthropometric and biochemical parameters ${ }^{(7-9)}$.
Bioelectrical impedance analysis (BIA) is a safe technique that estimates indirectly body composition by applying painless electric current. BIA-derived phase angle (PA) is an important parameter obtained from the result of the arctangent of reactance by resistance. Some authors have affirmed that PA reflects nutritional status and acts as indicator of prognosis in clinical practice, because PA is influenced by the degree of hydration and amount of intact cell membrane ${ }^{(10-12)}$. Therefore, both malnutrition and inflammatory processes interfere in final PA value - the lower PA values, the greater the severity of the underlying disease ${ }^{(13,14)}$.

In this context, this study aims to evaluate the impact of malnutrition on PA values, body water distribution, length of hospital stay and severe postoperative complications in patients with colorectal disease who underwent to elective major surgery at tertiary university hospital.

\section{METHODS}

\section{Setting and patients}

This retrospective and analytical cross-sectional study was approved by the Research Ethics Committee and was performed with

Declared conflict of interest of all authors: none

Disclosure of funding: no funding received

${ }^{1}$ Faculdade de Medicina de São José do Rio Preto, São José do Rio Preto, SP, Brasil. ${ }^{2}$ Faculdade de Medicina de São José do Rio Preto, Disciplina de Nutricão, Departamento de Enfermagem Geral, São José do Rio Preto, SP, Brasil. ${ }^{3}$ Faculdade de Medicina de São José do Rio Preto, Departamento de Cardiologia e Cirurgia Cardiovascular, São José do Rio Preto, SP, Brasil.

${ }^{4}$ Faculdade de Medicina de São José do Rio Preto, Disciplina de Coloproctologia, Departamento de Cirurgia, São José do Rio Preto, SP, Brasil.

Corresponding author: João Gomes Netinho. Orcid: https://orcid.org/0000-0003-0264-1883. E-mail: jgnetinho30@gmail.com 
40 patients admitted to tertiary university hospital (Base Hospital of São José do Rio Preto - SP - Brazil) during 2016 to 2018. All patients signed informed consent form beforehand. The inclusion criteria consisted of patients older than 18 years and younger than 80 years, hospitalized for elective abdominal major surgery via laparotomy or videolaparoscopy and who presented status I, II or III in the American Society of Anesthesiologist (ASA) system. The exclusion criteria were age less than 18 years or older than 80 years, patients with emergency operation indication or minor surgery, presence of limb amputation, impossibility to remain in the supine position or to communicate.

\section{Preoperative evaluation}

Patients were evaluated within 24 hours of hospital admission. The nutritional assessment was performed by a trained nutritionist. Initially, anthropometric data (weight and height) were obtained, followed by SGA application, which included weight changes in the last six months, functional capacity, gastrointestinal symptoms and clinical signs of malnutrition assessed by physical examination. From this data, patients were classified as well-nourished (A), mildly or moderately malnourished (B) and severely malnourished (C). For statistical purposes, patients were grouped into well-nourished (SGA: A) and malnourished (SGA: B + C).

BIA was performed with a portable analyzer (Biodynamics Model 450), which applies a painless electrical current of $800 \mu \mathrm{A}$ with a single frequency of $50 \mathrm{kHz}$. Patients were previously informed about the preparations for performing BIA according to all manufacturer's recommendations. The BIA-derived intracellular water (ICW), extracellular water (ECW) and total body water (TBW) were obtained from regression equations performed by the analyzer.

Biochemical data (hematocrit and serum albumin) were collected from electronic medical records according to the protocol established by the medical group.

\section{Postoperative evaluation}

The length of hospital stay was counted from admission to discharge. Postoperative outcomes were assessed according to Clavien-Dindo classification (CDC) of surgical complications. It is based on the type of therapy needed to correct the complication. All patients with grades III to $\mathrm{V}$ in the $\mathrm{CDC}$ were considered to have severe complication ${ }^{(15,16)}$. Grade III includes patients requiring surgical, endoscopic or radiological intervention; grade IV includes presence of one or more organic dysfunctions, requiring intensive care; and grade $\mathrm{V}$ includes deaths. The organic dysfunctions were evaluated by SOFA-score that is a tool commonly used in our service and was considered only new organic dysfunctions when SOFA-score $\geq 2^{(17)}$.

\section{Statistical analysis}

Variables were expressed as mean (SD), number (\%) or median (interquartile range) where appropriate. Inferential analyzes and binary logistic regression were performed using SPSS IBM 14. The Shapiro-Wilk test for normality was used and Student's t-test was applied to compare two parametric continuous variables, while Mann-Whitney test was performed in non-parametric samples. To determine the relationship between malnutrition and postoperative complications, Fisher's exact test was used for two qualitative variables. To obtain optimal PA cutoff value for malnutrition screening, ROC curve was performed using BioEstat 5.0 software. For all analyzes, $P<0.05$ was considered significant.

\section{RESULTS}

The study included 40 patients with a mean age of $59.4 \pm 12.3$ years of which $52.5 \%$ of patients were female. In the sample, 33 $(82.5 \%)$ patients were diagnosed with colorectal cancer, $03(7.5 \%)$ with Crohn's disease, $03(7.5 \%)$ with diverticular disease and 01 $(2.5 \%)$ with familial adenomatous polyposis (TABLE 1$)$.

TABLE 1. Patient characteristics $(n=40)$.

\begin{tabular}{lc}
\hline Variable & $\begin{array}{c}\text { M } \pm \text { SD or N (\%) or } \\
\text { m (IQR: Q3-Q1) }\end{array}$ \\
\hline Age (years) & $59.4 \pm 12.3$ \\
Gender & $19(47.5)$ \\
Male & $21(52.5)$ \\
Female & \\
Diagnosis & $33(82.5)$ \\
Neoplasm & $03(7.5)$ \\
Crohn's disease & $03(7.5)$ \\
Diverticular disease & $01(2.5)$ \\
Familial adenomatous polyposis & \\
SGA & $23(57.5)$ \\
A & $17(42.5)$ \\
B or C & \\
Clinical outcomes & $04(4-6)$ \\
Length of hospital stay (days) & $12(30.0)$ \\
Severe complications* & $02(5.0)$ \\
Death & \\
\hline M: mean; SD: standard deviation; N: number; m: median; IQR: interquartile range; Q1: \\
first quartile; Q3: third quartile; SGA: Subjective Global Assessment. * Degree III to V of \\
Clavien-Dindo classification.
\end{tabular}

According to the SGA, $17(42.5 \%)$ patients were diagnosed as moderately (SGA: B) or severely (SGA: C) malnourished and 23 $(57.5 \%)$ as well-nourished (SGA: A) during preoperative period. In the postoperative course, $12(30.0 \%)$ individuals developed severe complications (grade III, IV or V) that caused the death of $02(5.0 \%)$ of them (TABLE 1$)$.

In TABLE 2, patients were categorized into two groups according to the nutritional diagnosis by SGA. Malnourished group presented lower values of serum albumin $(P=0.012)$, hematocrit $(P=0.026)$ and PA $(P=0.002)$; meanwhile, ECW/ICW $(P=0.019)$ and ECW/TBW $(P=0.047)$ were higher. Although malnourished patients showed higher median length of hospital stay than wellnourished group, there was no statistical difference between these two nutritional status $(P=0.051)$.

TABLE 3 shows that $58.8 \%$ of malnourished patients developed severe postoperative complications compared to $8.7 \%$ of well-nourished individuals. The chance of severe complication in malnourished patients was at least $160 \%$ higher than in the well-nourished group $(P=0.001)$. Furthermore, using logistic regression model, malnutrition diagnosed by SGA was an independent predictor of severe postoperative complications $(P=0.002)($ TABLE 4$)$. 
TABLE 2. Anthropometric, biochemical, body composition data and length of hospital stay between different nutritional status groups according to the Subjective Global Assessment.

\begin{tabular}{lccc}
\hline & Well-nourished & Malnourished & \\
Variable & A (n=23) & B + C $(\mathbf{n}=17)$ & $P$ value \\
& M \pm DP or m (IQR: Q3-Q1) & \\
\hline Weight $(\mathrm{kg})$ & $74.7 \pm 12.2$ & $65.4 \pm 13.3$ & 0.077 \\
BMI $\left(\mathrm{kg} / \mathrm{m}^{2}\right)$ & $28.0 \pm 3.7$ & $26.1 \pm 5.0$ & 0.328 \\
Albumin $(\mathrm{g} / \mathrm{dl}){ }^{\#}$ & $4.2(4.6-4.0)$ & $3.9(3.6-4.2)$ & $0.012^{*}$ \\
Hematocrit $(\%)$ & $37.7 \pm 4.8$ & $34.7 \pm 4.1$ & $0.026^{*}$ \\
PA $\left({ }^{\circ}\right)$ & $6.5 \pm 0.7$ & $5.5 \pm 0.9$ & $0.002^{*}$ \\
Resistance $(\mathrm{ohm})$ & $512.9 \pm 82.6$ & $550.8 \pm 97.4$ & 0.213 \\
Reactance $(\mathrm{ohm})$ & $58.1 \pm 9.7$ & $52.7 \pm 11.9$ & 0.177 \\
Fat free mass $(\%)$ & $32.3 \pm 3.9$ & $29.8 \pm 3.8$ & 0.092 \\
ECW/TBW (\%) & $46.3 \pm 3.5$ & $49.3 \pm 3.8$ & $0.047 *$ \\
ECW/ICW ${ }^{\#}$ & $0.8(0.8-1.0)$ & $1.0(0.9-1.0)$ & $0.019 *$ \\
$\begin{array}{l}\text { Length of hospital } \\
\text { stay (days) }\end{array}$ & $4.0(3.0-5.0)$ & $5.0(4.0-10.0)$ & 0.051 \\
\hline
\end{tabular}

M: mean; SD: standard deviation; N: number; m: median; IQR: interquartile range: Q1: first quartile; Q3: third quartile. "Non-parametric data. PA: phase angle; ECW: extracellular water; TBW: total body water; ICW: intracellular water. * Significant difference $(P<0.05)$.

TABLE 3. Frequency of severe postoperative complications among wellnourished and malnourished patients.

\begin{tabular}{|c|c|c|c|c|}
\hline & \multicolumn{2}{|c|}{$\begin{array}{l}\text { Severe postoperative } \\
\text { complications } \mathrm{N}(\%)\end{array}$} & \multirow{2}{*}{ Total } & \multirow{2}{*}{ OR $(95 \% \mathrm{CI})$} \\
\hline & Yes & No & & \\
\hline Malnourished & $10(58.8)$ & $07(41.2)$ & $17(100)$ & $15.0(2.6-86.7)$ \\
\hline Well-nourished & $02(8.7)$ & $21(91.3)$ & $23(100)$ & $P=0.001 *$ \\
\hline Total & $12(30.0)$ & $28(70.0)$ & $40(100)$ & \\
\hline
\end{tabular}

OR: odds ratio; CI: confidence interval. *Significant result $(P<0.05)$ according to Fisher's exact test.

TABLE 4. Logistic regression analysis for severe postoperative complications.

\begin{tabular}{lcccc}
\hline \multicolumn{1}{c}{ Variable } & $\begin{array}{c}\text { B } \\
\text { (coefficient) }\end{array}$ & $\begin{array}{c}\operatorname{Exp} \\
(\mathbf{B})\end{array}$ & $\begin{array}{c}95 \% \mathrm{CI} \\
\text { for } \operatorname{Exp}(\mathrm{B})\end{array}$ & $\begin{array}{c}\boldsymbol{P} \\
\text { value }\end{array}$ \\
\hline Malnourished (SGA) & 2.708 & 15.000 & $2.626-85.681$ & 0.002 \\
Constant & -2.351 & 0.095 & & 0.001 \\
\hline
\end{tabular}

SGA = Subjective Global Assessment. $\mathrm{CI}$ = confidence interval.

The ROC curve-derived optimal PA cutoff value obtained was $6.0^{\circ}$, yielding a sensitivity, specificity, positive predictive value and negative predictive value of $76.5 \%, 87.0 \%, 81.3 \%$ and $83.4 \%$, respectively. The area under the curve still showed great accuracy in discriminating between well-nourished and malnourished patients $(\mathrm{AUC}=0.82, P=0.001)(\mathrm{TABLE})$.
TABLE 5. ROC curve-derived optimum phase angle value for malnutrition screening.

\begin{tabular}{lccccccc}
\hline & $\begin{array}{c}\text { AUC } \\
(95 \% \text { CI })\end{array}$ & Cut-off & $\begin{array}{c}\text { S } \\
(\%)\end{array}$ & $\begin{array}{c}\text { E } \\
(\%)\end{array}$ & $\begin{array}{c}\text { PPV } \\
(\%)\end{array}$ & $\begin{array}{c}\text { NPV } \\
(\%)\end{array}$ & $\begin{array}{c}\boldsymbol{P} \\
\text { value }\end{array}$ \\
\hline $\begin{array}{l}\text { Phase } \\
\text { angle }\end{array}$ & $\begin{array}{c}0.82 \\
(0.65-0.95)\end{array}$ & $6.0^{\circ}$ & 76.5 & 87.0 & 81.3 & 83.4 & 0.001 \\
\hline
\end{tabular}

AUC: area under curve; S: sensibility; E: specificity; PPV: positive predictive value; NPV: negative predictive value.

\section{DISCUSSION}

\section{Malnutrition and postoperative complications}

In the present study, $42.5 \%$ of patients presented malnutrition on admission. Most of the hospitalized patients had colorectal cancer, justifying the high prevalence of malnutrition and the need for nutritional screening on hospital admission ${ }^{(2,4,18)}$. Correia et al. ${ }^{(1)}$ identified nine Brazilian studies that performed SGA to determine the prevalence of hospital malnutrition in surgical patients between 1994 and 2014. The authors found $17.6 \%$ to $66.0 \%$ of malnutrition prevalence mainly in patients who underwent gastrointestinal resection or colon surgeries. This wide prevalence is related to multiple factors involved in the development of malnutrition, such as, previous socioeconomic status, comorbidities, disease progression, previous chemotherapy or radiotherapy treatment and degree of hospital complexity.

In our study, malnourished patients presented lower values of albumin and hematocrit in comparison with well-nourished group, resulting in less physiological reserve to metabolic response to trauma and worse clinical evolution than malnourished group ${ }^{(19,20)}$. Some authors reported that serum albumin level less than 4.0 to 4.5 $\mathrm{g} / \mathrm{dL}$ is associated with increase in number of complication cases, length of hospital stay and postoperative mortality after intestinal resections due to dysfunction in collagen synthesis and formation of granulation tissue that impair the tissue healing ${ }^{(21,22)}$. The median level of albumin was less than $4.0 \mathrm{~g} / \mathrm{dL}$ in the malnourished group. This result warned us about the impairment healing process and postoperative recovery in this nutritional status.

Several studies have already shown that malnutrition increases the risk of postoperative complications, length of hospital stay, hospital costs and mortality ${ }^{(1,23,24)}$. In this context, our results showed high prevalence of severe postoperative complications $(30.0 \%)$, predominantly in the malnourished group. Maurício et al. ${ }^{(25)}$ evaluated patients who underwent elective surgery for colorectal cancer and identified similar rate of postoperative complications $(33.3 \%)$, but their results are overestimated because the authors considered complication grades II to $\mathrm{V}$ in the $\mathrm{CDC}$. However, using the same criteria for severe postoperative complications as our study, Mosquera et al. ${ }^{(4)}$ found $15.0 \%$ of complications in patients who have underwent major elective gastrointestinal surgery. Whereas, Härter et al. ${ }^{(14)}$ obtained $18.7 \%$ of outcomes after oncologic surgery. These two studies identified higher frequency and severity of complications in malnourished patients than in well-nourished, as observed in our study, which the odds was at least 1.6 times greater to develop severe postoperative complications compared to well-nourished individuals.

Furthermore, according to logistic regression, it was verified that malnutrition was an independent predictor factor for the development of severe postoperative complications, as well as observed by other authors ${ }^{(4,10,25)}$. Although the malnourished group did not show a longer hospital stay compared to the well-nourished group, the worst clinical outcome occurred in two malnourished patients who died during hospitalization. 


\section{Bioelectrical impedance analysis: phase angle and body water}

The resistance and reactance were possible using BIA. These two variables were directly detected by the analyzer without performing regression equations ${ }^{(26)}$. Higher amount of intact cell membrane indicates greater cellularity and so higher reactance and PA values. Therefore, PA is an indirect marker of membrane integrity and cellular vitality. Certain conditions such as malnutrition and inflammatory processes alter the electrical properties of cells and result in decrease of $\mathrm{PA}^{(10)}$. As our sample consisted of patients living with consumptive or chronic inflammatory diseases, it was expected reduction in PA in comparison to healthy individuals, especially because cellular catabolism and inflammatory process are intensified in these clinical conditions ${ }^{(27)}$. These metabolic alterations trigger higher consumption of body cell mass and, consequently, lead to decrease in cellularity. In our study, there was decrease in the mean PA among malnourished patients compared to well-nourished group. These results are in accordance with other authors $^{(5,24)}$, including Gupta et al. ${ }^{(28)}$ that followed hospitalized individuals with malnutrition and colorectal cancer.

In the literature, there is no well-established PA cutoff value to determine the nutritional status. The cutoff varies according to ethnic factors, gender, age, weight, length and morbid conditions ${ }^{(10)}$. In order to use PA as a marker of malnutrition, the characteristics of the ROC curve were analyzed and an optimum cut-off was estimated $\left(\mathrm{PA}=6.0^{\circ}\right)$. Therefore, $\mathrm{PA}<6.0^{\circ}$ showed an accuracy of $82.5 \%$ to identify malnourished patients. (FIGURE 1 ). This great PA accuracy contributes towards malnutrition screening marker in clinical practice since BIA is a non-invasive tool that is easy and quick to perform. Gupta et al. ${ }^{(28)}$ performed SGA in patients with colorectal cancer and found PA cut-off of $6.0^{\circ}$, yielding $82.2 \%$ of

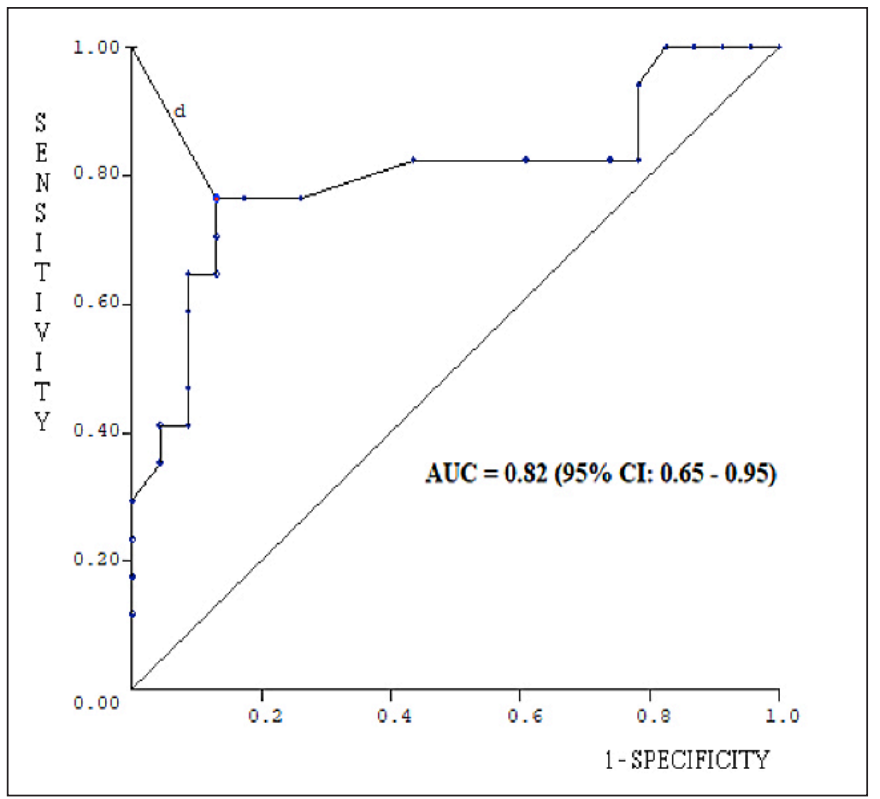

FIGURE 1 . The ROC curve of phase angle showing accuracy of $82 \%$ for diagnosis of malnutrition in screening nutritional assessment. sensitivity and $54.5 \%$ of specificity. Lukaski et al. ${ }^{(10)}$ found only two studies between 2012 to 2017 that evaluated the optimum PA cutoff to screening malnutrition by SGA. The first study was performed by Kyle et al. ${ }^{(29)}$ who obtained different cutoff for men $\left(5.0^{\circ}\right)$ and women $\left(4.6^{\circ}\right)$, with lower sensitivity and specificity values and accuracy $(83 \%)$ similar to those found in our study. In the second study ${ }^{(30)}$, sensitivity and specificity were $80.0 \%$ and $56.7 \%$, respectively, using PA cutoff of $4.7^{\circ}$. Therefore, although there are no well-established cutoff values, it is expected that more studies will define cutoff values adjusted for each particular clinical scenario.

In addition, as PA reduction represents loss of membrane integrity, it is possible to infer that cells also become unable to maintain adequate ratios of ICW. This fact allows to excessive displacement of intracellular fluid to the extracellular space and to increase the proportion of ECW/ICW, justifying the highest $\mathrm{ECW} / \mathrm{ICW}$ value in malnourished group. Changes in cell size, cell permeability and fluid distribution in tissues determine PA values ${ }^{(11)}$. Although the increase in ECW/ICW and ECW/TBW ratio did not impact the postoperative complications in our study, some authors related increasing ECW to worse outcomes. For example, Ohashi et al. ${ }^{(31)}$ associated increasing ECW/ICW with unfavorable clinical outcomes in malnourished elderly patients with chronic kidney disease ${ }^{(32)}$. In Korea, Lee et al. ${ }^{(33)}$ followed severely malnourished patients at intensive care unit and found significant fluid imbalance characterized by higher proportion of ECW/TBW compared to well-nourished individuals; and the increase in this ratio was higher in patients who died.

\section{CONCLUSION}

In conclusion, the present study showed high prevalence of malnutrition prior to major surgical procedure and severe postoperative complications, of which malnutrition was independent predictive factor for its occurrence. Our results confirmed that malnutrition is associated with lower values of PA and greater distribution of water in the extracellular compartment. We also revealed that PA presented high accuracy in nutritional screening, implying a useful malnutritional marker.

The limitations of this study include the evaluation of patients from only a single medical center; limited sample size; and heterogeneity of group that consisted of patients with colorectal cancer at different stages of treatment.

\section{ACKNOWLEDGEMENTS}

We would like to thank the Base Hospital of São José do Rio Preto (Brazil) and the Faculty of Medicine of São José do Rio Preto (FAMERP) for their technical and financial assistance.

\section{Authors' contribuition}

Nishiyama VKG: data collection, survey execution, interpretation of the data and writing of text. Albertini SM: data collection and interpretation of the data. Moraes CMZG: data collection, survey execution and interpretation of the data. Godoy MF: statistical analysis. Netinho JG: conception, design of the research and interpretation of the data. 
Nishiyama VKG, Albertini SM, Moraes CMZG, Godoy MF, Netinho JG. Desnutrição e complicações clínicas em pacientes cirúrgicos com doença colorretal. Arq Gastroenterol. 2018;55(4):397-402.

RESUMO - Contexto - A desnutrição é uma condição frequente entre pacientes hospitalizados e é um fator de risco para complicações pós-operatórias. Objetivo - Este estudo tem como objetivo avaliar o impacto da desnutrição sobre o ângulo de fase (AF), a distribuição de água corporal e complicações clínicas em pacientes cirúrgicos com doença colorretal. Métodos - Trata-se de um estudo retrospectivo realizado em um hospital universitário terciário com 40 pacientes admitidos eletivamente. Na avaliação pré-operatória, foram realizadas a avaliação subjetiva global e análise de bioimpedância elétrica com a finalidade de determinarem o estado nutricional, AF, água extracelular (AEC), água intracelular (AIC) e água corporal total (ACT). $\mathrm{Na}$ avaliação pós-operatória, o tempo de internação hospitalar e a presença de complicações graves, segundo a classificação de Clavien-Dindo, foram determinados. O melhor ponto de corte do AF para o rastreamento de desnutrição foi obtido a partir da análise da curva ROC. Resultados - Dezessete $(42,5 \%)$ pacientes foram diagnosticados como desnutridos e 23 (57,5\%), como bem nutridos de acordo com a avaliação subjetiva global. Doze (30,0\%) pacientes desenvolveram complicações pós-operatórias graves. O grupo desnutrido apresentou menores valores de albumina sérica $(P=0,012)$, hematócrito $(P=0,026)$ e $\operatorname{AF}(P=0,002)$; enquanto que as relações de $\operatorname{AEC/AIC~}(P=0,019)$ e AEC/ACT $(P=0,047)$ estiveram elevadas. Além disso, $58,8 \%$ dos pacientes desnutridos desenvolveram complicações pós-operatórias graves em comparação a $8,7 \%$ dos pacientes bem nutridos. A desnutrição foi fator preditivo independente para o desenvolvimento de complicações pós-operatórias graves ( $\mathrm{OR}=15,00, \mathrm{IC}: 2,63-85,68 ; P=0,002)$. O melhor ponto de corte do AF obtido foi $6.0^{\circ}$ (AUC=0,82; $P=0,001$ ) com sensibilidade, especificidade, valor preditivo positivo e valor preditivo negativo de $76,5^{\circ}$, $87,0 \%, 81,3 \%$ e 83,4\%, respectivamente. Conclusão - A desnutrição foi fator preditivo para o desenvolvimento de complicações graves em pacientes submetidos à cirurgia eletiva coloproctológica de grande porte. Além disso, a desnutrição foi associada a menores valores de AF e maior proporção de AEC. O AF forneceu boa acurácia no rastreamento da desnutrição, sugerindo seu uso como potencial marcador de desnutrição.

DESCRITORES - Desnutrição. Impedância elétrica. Avaliação nutricional. Cirurgia colorretal.

\section{REFERENCES}

1. Correia MITD, Perman MI, Waitzberg DL. Hospital malnutrition in Latin America: A systematic review. Clin Nutr. 2017;36:958-67.

2. Weimann A, Braga M, Carli F, Higashiguchi T, Hübner M, Klek S, et al. ESPEN guideline: Clinical nutrition in surgery. Clin Nutr. 2017;36:623-50.

3. Wahid H, Ahmad S, Nor MAM, Rashid MA. Prestasi kecekapan pengurusan kewangan dan agihan zakat: perbandingan antara majlis agama islam negeri di Malaysia. J Ekon Malaysia. 2a. 2017;51:39-54.

4. Mosquera C, Koutlas NJ, Edwards KC, Strickland A, Vohra NA, Zervos EE, et al. Impact of malnutrition on gastrointestinal surgical patients. J Surg Res. 2016;205:95-101.

5. Hu WH, Cajas-Monson LC, Eisenstein S, Parry L, Cosman B, Ramamoorthy S. Preoperative malnutrition assessments as predictors of postoperative mortality and morbidity in colorectal cancer: an analysis of ACS-NSQIP. Nutr J. 2015;14:91.

6. Leandro-Merhi VA, Aquino JLB. Relationship between nutritional status and the clinical outcomes of patients with and without neoplasms according to multiple correspondence analysis. Arq Gastroenterol. 2017;54:148-55.

7. Fidelix MSP. Manual orientativo: Sistematização do cuidado de nutrição. Assoc Bras Nutr. 2014;66.

8. Moriana M, Civera M, Artero A, Real JT, Caro J, Ascaso JF, et al. Validity of subjective global assessment as a screening method for hospital malnutrition. Prevalence of malnutrition in a tertiary hospital. Endocrinol Nutr. 2014;61:184-9.

9. Mueller C, Compher C, Ellen DM. A.S.P.E.N. clinical guidelines: Nutrition screening, assessment, and intervention in adults. JPEN J Parenter Enteral Nutr. 2011;35:16-24

10. Lukaski HC, Kyle UG, Kondrup J. Assessment of adult malnutrition and prognosis with bioelectrical impedance analysis: phase angle and impedance ratio. Curr Opin Clin Nutr Metab Care. 2017;20:330-9.

11. Gonzalez MC, Barbosa-Silva TG, Bielemann RM, Gallagher D, Heymsfield SB. Phase angle and its determinants in healthy subjects: influence of body composition. Am J Clin Nutr. 2016;103:712-6.

12. Stapel SN, Looijaard WGPM, Dekker IM, Girbes ARJ, Weijs PJM, Oudemans-van Straaten HM. Bioelectrical impedance analysis-derived phase angle at admission as a predictor of 90-day mortality in intensive care patients. Eur $\mathbf{J}$ Clin Nutr. 2018;1-7.
13. Stobäus N, Pirlich M, Valentini L, Schulzke JD, Norman K. Determinants of bioelectrical phase angle in disease. Br J Nutr. 2012;107:1217-20.

14. Härter J, Orlandi SP, Gonzalez MC. Nutritional and functional factors as prognostic of surgical cancer patients. Support Care Cancer. 2017;25:2525-30.

15. Moreira LF, Pessôa MC, Mattana DS, Schmitz FF, Volkweis BS, Antoniazzi JL, et al. Cultural adaptation and the Clavien-Dindo surgical complications classification translated to Brazilian Portuguese. Rev Col Bras Cir. 2016;43:141-8.

16. Clavien PA, Barkun J, de Oliveira ML, Vauthey JN, Dindo D, Schulick RD, et al. The Clavien-Dindo classification of surgical complications: five-year experience. Ann Surg. 2009;250:187-96.

17. Vincent JL, De Mendonça A, Cantraine F, Moreno R, Takala J, Suter PM, et al. Use of the SOFA score to assess the incidence of organ dysfunction/failure in intensive care units: Results of a multicenter, prospective study. Crit Care Med. 1998;26:1793-800.

18. Brasil. Consenso nacional de nutrição oncológica. Vol. 53, Ministerio da Saúde. Instituto Nacional de Câncer. 2013. 126 p.

19. Moghadamyeghaneh Z, Hwang G, Hanna MH, Phelan MJ, Carmichael JC, Mills $\mathrm{SD}$, et al. Even modest hypoalbuminemia affects outcomes of colorectal surgery patients. Am J Surg. 2015;210:276-84.

20. Meyer CP, Rios-Diaz AJ, Dalela D, Ravi P, Sood A, Hanske J, et al. The association of hypoalbuminemia with early perioperative outcomes - A comprehensive assessment across 16 major procedures. Am J Surg. 2017;214:871-83.

21. Truong A, Hanna MH, Moghadamyeghaneh Z, Stamos MJ. Implications of preoperative hypoalbuminemia in colorectal surgery. World J Gastrointest Surg. 2016;8:353-62.

22. Kudsk KA, Tolley EA, DeWitt RC, Janu PG, Blackwell AP, Yeary S, et al. Preoperative albumin and surgical site identify surgical risk for major postoperative complications. JPEN J Parenter Enter Nutr. 2003;27:1-9.

23. Asiimwe SB, Muzoora C, Wilson LA, Moore CC. Bedside measures of malnutrition and association with mortality in hospitalized adults. Clin Nutr. 2015; 34:252-6.

24. Barao K, Abe Vicente Cavagnari M, Silva Fucuta P, Manoukian Forones N. Association Between Nutrition Status and Survival in Elderly Patients With Colorectal Cancer. Nutr Clin Pr. 2017;32:658-63. 
25. Maurício SF, Xiao J, Prado CM, Gonzalez MC, Correia MITD. Different nutritional assessment tools as predictors of postoperative complications in patients undergoing colorectal cancer resection. Clin Nutr. 2017.

26. Khalil SF, Mohktar MS, Ibrahim F. The theory and fundamentals of bioimpedance analysis in clinical status monitoring and diagnosis of diseases. Sensors (Basel). 2014;14:10895-928.

27. Abe Vicente M, Donizetti Silva T, Barão K, Vitor Felipe A, Oyama Missae L, Manoukian Forones N. The influence of nutritional status and disease on adiponectin and TNF- $\alpha$; levels in colorectal cancer patients. Nutr Hosp. 2014;30:140-6.

28. Gupta D, Lis CG, Dahlk SL, King J, Vashi PG, Grutsch JF, et al. The relationship between bioelectrical impedance phase angle and subjective global assessment in advanced colorectal cancer. Nutr J. 2008;7:19.

29. Kyle UG, Soundar EP, Genton L, Pichard C. Can phase angle determined by bioelectrical impedance analysis assess nutritional risk? A comparison between healthy and hospitalized subjects. Clin Nutr. 2012;31:875-81.
30. Małecka-Massalska T, Mlak R, Smolen A, Morshed K. Bioelectrical impedance phase angle and subjective global assessment in detecting malnutrition among newly diagnosed head and neck cancer patients. Eur Arch Otorhinolaryngol. 2016;273:1299-305.

31. Ohashi Y, Tai R, Aoki T, Mizuiri S, Ogura T, Tanaka Y, et al. The Associations of Malnutrition and Aging with Fluid Volume Imbalance between Intra- and Extracellular Water in Patients with Chronic Kidney Disease. J Nutr Heal Aging. 2015;19:986-93.

32. Ohashi Y, Saito A, Yamazaki K, Tai R, Matsukiyo T, Aikawa A, et al. Brain Natriuretic Peptide and Body Fluid Composition in Patients with Chronic Kidney Disease: A Cross-Sectional Study to Evaluate the Relationship between Volume Overload and Malnutrition. Cardiorenal Med. 2016;6:337-46.

33. Lee Y, Kwon O, Shin CS, Lee SM. Use of bioelectrical impedance analysis for the assessment of nutritional status in critically ill patients. Clin Nutr Res. 2015; $4: 32-40$ 